\title{
Peran Iklim Kerja dalam Pembentukan Iklim Madrasah Islami (Studi di MTs Al-Muttaqin Pekanbaru, Riau)
}

\author{
Rini Setyaningsih, Sizka Farwati, Alfian Sujayono \\ Universitas Islam Negeri Sultan Syarif Kasim Riau \\ Email: rini.setyaningsih@uin-suska.ac.id
}

\begin{abstract}
This research is descriptive qualitative which aims to find out how the work climate of MTs Al-Muttaqin and how the role of the work climate of MTs Al-Muttaqin forms the climate of Islamic in the Islamic School. In collecting data, the writer used the method of interviewing and observing several MTs Al-Muttaqin residents. Overall data obtained through interviews, the author of the analysis uses data reduction techniques, data interpretation, and triangulation, while the data obtained from observations, the author makes field notes and then makes the interpretation of the recording results. The results of this study indicate that the working climate at MTs Al-Muttaqin has met the criteria of a good working climate, which can be used as an example for other Islamic School. Data in the field shows that the work climate at MTs Al-Muttaqin already contained values that can shape the climate of Islamic in the Islamic School. These values are faith and morality, commitment and excellence, fairness and solidarity, trust worthy and serving others. Evidenced by a sense of responsibility, fairness, work hard, work whole heartedly, solidarity and have a sense of good service from the headmaster of foundations, headmaster of Islamic School, teachers and students, as well as guardians of students and the community.
\end{abstract}

Keywords: Madrasah, Working Climate, Islamic Climate

Abstrak: Penelitian ini bersifat deskriptif kualitatif yang bertujuan untuk mengetahui bagaimana iklim kerja MTs Al-Muttaqin dan bagaimana peran iklim kerja MTs Al-Muttaqin membentuk iklim madrasah Islami. Dalam pengumpulan data, penulis menggunakan metode wawancara dan observasi kepada beberapa warga MTs Al-Muttaqin. Keseluruhan data yang diperoleh melalui wawancara, penulis analisis menggunakan teknik reduksi data, interpretasi data, dan triangulasi, sedang data yang diperoleh dari observasi, penulis membuat catatan lapangan kemudian membuat interpretasi hasil pencatatan. Hasil dari penelitian ini menyebutkan bahwa iklim kerja di MTs AlMuttaqin sudah memenuhi kreteria iklim kerja yang baik, yang dapat dijadikan contoh untuk madrasah lainya. Data di lapangan menunjukkan bahwa iklim kerja di MTs Al-Muttaqin sudah mengandung nilai-nilai yang dapat membentuk iklim madrsah Islami. Nilai-nilai tersebut adalah iman dan akhlaq, Iltizam dan Jiddiyah, Adil dan ukhuwwah, Amanah dan khidmah. Terbukti dengan adanya rasa tanggung jawab, adil, bekerja keras, bekerja sepenuh hati, ukhuwah dan memiliki rasa melayani baik dari pimpinan yayasan, madrasah, guru dan murid, serta para wali murid dan masyarakat.

Kata Kunci: Madrasah, Iklim Kerja, Iklim Islami 


\section{PENDAHULUAN}

Setiap lembaga pendidikan akan selalu berusaha untuk meningkatkan mutu pendidikan nya. Upaya yang bisa di lakukan oleh lembaga pendidikan dalam meningkatkan mutu pendidikan ialah salah satunya membangun iklim kerja yang kondusif agar seluruh kegiatan pengelolaan lembaga pendidikan dapat berjalan dengan maksimal dan membuahkan hasil yakni peningkatan mutu lembaga pendidikan secara terus menerus. Proses penyelenggaraan pendidikan akan ada interaksi antar sesama manusia penyelengara dalam sebuah pendidikan dengan sistem yang terarah dan terkoordinir untuk pencapaian sebuah tujuan pendidikan. Dalam lembaga pendidikan diperlukan pembagian tugas dan tanggung jawab serta hubungan kerja yang jelas. Tugas ini disesuaikan dengan ruang lingkup pekerjaan dan keadaan personelnya.

1 Indonesia, Keputusan Menteri Agama Republik Indonesia Nomor: 165 Tahun 2014 tentang Kemendikbud. (2013).
Seorang pemimpin Madrasah dapat dibantu beberapa orang wakil kepala Madrasah yang mengkoordinasikan urusan kurikulum atau kegiatan belajar mengajar, urusan kesiswaan, urusan sarana dan prasarana pendidikan, urusan hubungan antara sekolah dengan masyarakat dan sebagainya. Namun untuk tercapainya tujuan dengan baik dalam pelaksanaan tugas dan tanggung jawab personel, dibutuhkan pula iklim atau lingkungan kerja yang kondusif.

Pelaksanaan pendidikan di Indonesia di atur secara baku berlandaskan UU Sisdiknas No. 20/tahun 2013. ${ }^{1}$ Berdasarkan pasal 1 ayat 1, maka tujuan utama pendidikan adalah menghasilkan siswa didik yang memiliki kualitas spiritual keagamaan, kepribadian dan akhlak mulia. Pasal dan ayat ini sekaligus menjelaskan kekhasan tujuan pendidikan di Indonesia yang tidak dapat dilepaskan dari aspek

Kurikulum 2013 Mata Pelajaran Pendidikan Agama Islam dan Bahasa Arab Pada Madrasah. 
religius. Pertimbangan religius ini juga diakomodir oleh para pengambil kebijakan dalam pemerintahan, yang tercermin melalui aturan,prosedur, UU dan petunjuk pelaksanaan pendidikan. Aturan dan nilai religius yang ada dalam masyarakat perlu dipertimbangkan dalam penyusunan norma dan tujuan sekolah sehingga mengikat warga sekolah untuk memiliki perilaku tertentu yang sesuai dengan tujuan besar pendidikan sekolah berbasis ajaran agama Islam.

Iklim kerja sebagai suatu konsep yang mereflesikan isi dan kekuatan nilai-nilai umum, norma, sikap, tingkah laku, dan perasaan anggota terhadap suatu sistem. Iklim kerja disekolah diidentifikasikan sebagai perangkat atribut yang memberi warna atau karakter, spirit, etos, suasana batin, dari setiap Madrasah secara operasional, sebagaimana halnya

2RyanW, Linksbetweenschoolclimateandbullying: Astudyof twotribesschools. 2009, pengertian iklim pada cuaca, iklim kerja di Madrasah diukur dengan menggunakan rata-rata dari persepsi komunitas Madrasah terhadap aspek-aspek yang menentukan lingkugan kerja. Tak lepas dari lembaga pendidikan Islam atau Madrasah, bahwa pembentukan iklim kerja madrasah yang Islami sangat diperlukan guna melancarkan keseluruhan aspek dan proses pendidikan yang ada di Madrasah. Pembentukan iklim kerja madrasah yang Islami tak semudah membalikkan kedua tangan, namun memerlukan ide, kreasi, komitmen, dan kemauan serta niat yang tulus untuk dapat mencapainya.

Iklim Madrasah merupakan jantung dan ruh yang membuat guru ataupun siswa memiliki perasaan tertentu pada sekolahnya, seperti perasaan senang atau justru sebaliknya.2 Sekolah yang memiliki iklim yang positif akan mengundang guru dan siswa merasa nyaman

view $/ 205390932$ ?accountid $=17242$

(Diakses pada tanggal 16 Desember 2019, pukul 19:00 WIB) 
berada didalamnya dan mendorong mereka untuk menampilkan kemampuan terbaiknya. ${ }^{3}$

\section{METODOLOGI}

Jenis penelitian ini menggunakan metode penelitian kualitatif. Penelitian kualitatif merupakan penelitian yang bersifat deskriptif dan lebih ditujukan untuk memahami suatu kejadian atau fenomena-fenomena dari sudut pandang partisipan. Dalam penelitian ini, penulis mengambil tempat dalam pendidikan formal yang berjenjang Tsanawiyah swasta yaitu Madrasah Tsanawiyah AlMuttaqin Pekanbaru yang merupakan lembaga pendidikan yang berdedikasi Islam, yang mana terletak di lahan strategis, yaitu di JL HR. Subrantas KM 13,5 Kelurahan Tuah Karya, Kec Tampan, Kota Pekanbaru.

Penulis menggunakan metode wawancara dan observasi kepada

3 Jimerson, S.R., Swearer, S.M., \& Espelage, D.L, International Handbook of SchoolBullying: An International-Perspective. 2009, beberapa subjek sekolah di antaranya: Kepala Madrasah, guru, pegawai tata usaha, bagian Humas, penjaga sekolah (SATPAM), dan Pekerja kebersihan, serta beberapa peserta didik yang penulis pilih secara random. Tinjauan langsung penulis dengan memfokuskan pada hal-hal yang terkait tentang iklim kerja di MTS Al-Muttaqin yakni meninjau tentang keadaan hati, suasana, tempat dan hal-hal yang berkaitan dengan keadaaan umum maupun khusus di lembaga tersebut. Sehingga pembahasan penelitian ini merupakan hasil dari jawaban dan hasil observasi yang telah terfokus pada rumusan kajian yaitu Iklim Kerja Madrasah di Mts Al-Muttaqin Pekanbaru.Teknik analisis data yang digunakan penulis dalam penelitian ini yakni mencakup transkip hasil wawancara, reduksi data, analisis, interpretasi data dan triangulasi.

darihttps://books.google.co.id/books?id= d2- NAgAAQBAJ(Diakses pada tanggal 16 Desember 2019, pukul 19:00 WIB) 


\section{PEMBAHASAN}

\section{A. Pengertian Iklim Kerja \\ Sekolah/Madrasah}

Menurut Litwin dan Stringer dalam Hoy dan Miskel, iklim kerja adalah seperangkat sifat terukur dari lingkungan kerja, berdasarkan persepsi kolektif masyarakat yang tinggal dan bekerja di lingkungan terbukti dapat mempengaruhi tingkah laku mereka. Bertolak pada pendapat tersebut Marzuki dalam Supardi mengemukakan bahwa iklim kerja sekolah adalah keadaan sekitar sekolah dan suasana yang sunyi dan nyaman yang sesuai dan kondusif untuk pembelajaran sebagai peningkat prestasi akademik. ${ }^{4}$ Yang tergambar pada keadaan warga sekolah baik keadaan riang dan mesra ataupun kepedulian antara satu sama lainnya. Karena hubungan mesra pada iklim kerja sekolah terjadi disebabkan apabila terdapat hubungan yang baik di antara kepala sekolah, guru, dan diantara guru dan peserta didik. Sehingga dapat dikatakan Iklim kerja yang kondusif akan menciptakan hubungan yang baik antara kepala sekolah, guru, karyawan dan peserta didik yang merupakan aspek terpenting dalam meningkatkan hasil kinerja guru. ${ }^{5} \mathrm{Hal}$ ini berarti Iklim kerja sekolah akan berdampak pada kinerja guru yang mencerminkan bahwa suasana sekolah yang kondusif sangat mendukung peningkatan kinerja guru. Selain itu, dengan terjaganya iklim sekolah dapat memberikan dampak positif bagi sekolah, yakni adanya rasa aman dan nyaman, disiplin, proses belajar mengajar berlangsung lancar, dan adanya daya saing siswa dan alumni. Hal ini menandakan bahwa siswa akan memperoleh pengetahuan, keterampilan, perubahan sikap siswa kearah lebih baik. Dari berbagai dampak tersebut memberikan gambaran bahwa iklim sekolah yang positif sangat memegang peranan

5 Yamin dan Maisah, Standarisasi Kinerja Guru, (Jakarta: Gaung Persada Press 2010), 53 
penting untuk kemajuan sekolah. ${ }^{6}$

Sehingga iklim sekolah yang efektif akan memberikan efek positif bagi semua unsur dan personil sekolah seperti kepala sekolah, guru, staf, siswa dan masyarakat. ${ }^{7}$ Yang akan tergambar melalui iklim kerja yang baik terlihat dari kinerja yang berkualitas.

Dalam hal tersebut, menurut penulis dapat diambil kesimpulan dari pembahasan di atas bahwa iklim kerja sekolah/madrasah adalah suasana, keadaan ataupun kualitas dari madrasah untuk membantu individu masing-masing merasa berharga secara pribadi, bermartabat dan penting, dan secara serentak dapat membantu terciptanya suatu perasaan memiliki terhadap segala sesuatu di sekitar lingkungan sekolah. Tentu berkaitan dengan sifat-sifat atau ciri yang dirasa dalam sebuah

6 Irwan, Iklim Sekolah di SMKN 1 Papalang Kabupaten Mamuju, Jurnal Eklektika Volume 4 Nomor 1, April 2016, hlm 61. Dalam http://ojs.unm.ac.id/ekletika/article/dowlo ad/5675/3312 diakses pada tanggal 22 Desember 2019, pukul 11:26. lingkungan

kerja

sekolah/madrasah, timbul karena adanya kegiatan dilakukan secara sadar atau tidak, yang dianggap mempengaruhi tingkah laku sebagai sudut pandang keperibadian organisasi seperti yang dilihat oleh paraanggotanya.

Sebagai dasar acuan dari iklim kerja yang baik dapat dilihat dari proses komunikasi yang terjalin. Karena proses komunikasi merupakan faktor yang sangat esensial untuk terciptanya iklim kerja yang kondusif. Tergambar dari kodrat manusia yaitu satu sama lain saling berhubungan dan membutuhkan, dimana hal ini dapat terwujud melalui proses komunikasi. Proses komunikasi berfungsi mengikat masing-masing anggota sekolah menjadi satu bagian yang integral utuh dan bersatu. Ikatan yang terbentuk

${ }^{7}$ Astuti, Pengembangan Budaya dan Iklim Sekolah, diambil dari http://jurnal.iainbone.ac.id/index.php/adara/article/dowloa d/267/217. (diakses pada tanggal 22 desember 2019, pukul 11:24) 
karena komunikasi yang harmonis dan lancar akan mendorong semangat kerjasama dan menumbuhkan sikap peduli dengan lingkungan kerja. Tanpa komunikasi pikiran kita tidak dapat mengembangkan sikap alami manusia yang asli tetapi tetap dalam keadaan yang tidak normal dan sikap yang lebih kasar.Kutipan ini mengisaratkan supaya setiap komponen sekolah membuat satu sistem komunikasi kerjasama yang harmonis sehingga tercipta iklim kerja yang kondusif dan harmonis.

Berdasarkan penjelasan pertanyaan dari beberapa narasumber dapat tergambar tentang keadaan dan suasana di lingkungan MTS Al-Muttaqin, sehingga dapat memberi gambaran kepada penulis, bahwa iklim kerja dalam setiap elemen-elemen madrasah yang ada, baik dari tenaga pendidik, tata usaha, satpam, bagian kebersihan dan para peserta didik sangat baik, dan

8 Suharmisi Arikunto. Dasar-dasar Evaluasi Pendidikan, (Jakarta: Bumi Aksara 2008), 35-38. menjadikan MTs Al-Muttaqin suatu lembaga yang berkategori tempat yang menyenangkan. Hal tersebut terlihat dari anggapan objek wawancara (informan) di MTs AlMuttaqin yang benar-benar mengakui sangat merasakan hal yang menyenangkan di lembaga pendidikan tersebut.

\section{B. Jenis-jenis Iklim Kerja Sekolah/Madrasah}

Iklim-iklim organisasi sekolah dapat digolongkan sebagai berikut: ${ }^{8}$

1. Iklim terbuka, yaitu suasana yang melukiskan organisasi sekolah yang penuh semangat dan daya hidup, memberikan kepuasan pada anggota kelompok dalam memenuhi kebutuhankebutuhan, dan tindakan pemimpin yang sejalan dan serasi. Iklim sekolah/ madrasah terbuka didasarkan pada rasa hormat, kepercayaan dan 


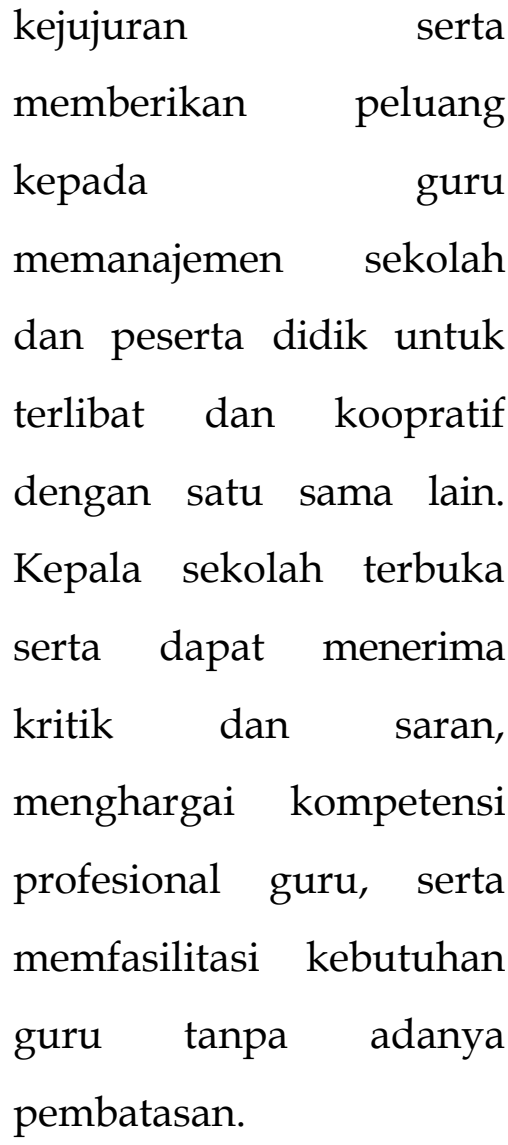

2. Iklim bebas yaitu melukiskan suasana organisasi sekolah/ madrasah dimana tindakan kepemimpinan justru muncul dari anggota kelompok. Pemimpin kurang melaksanakan pengawasan, semangat kerja muncul hanya untuk memenuhi kepuasan pribadi.

3. Iklim terkontrol yaitu bercirikan impersonal dan pemimpin sangat mementingkan tugas, sementara kebutuhan pribadi anggota organisasi sekolah tidak diperhatikan.

4. Iklim familier yaitu suatu iklim yang terlalu bersifat manusiawi dan tidak terkontrol. Para anggota hanya berlomba-lomba untuk memenuhui tuntunan pribadi mereka, namun sangat sedikit perhatian pada penyelesain tugas dan kontrol sosial.

5. Iklim tertutup, para anggota biasanya bersikap acuh atau masa bodoh, rendahnya motivasi dari pemimpin, organisasi tidak maju, semangat bekerja kelompok rendah, karena para anggota di samping tidak terpenuhinya tuntunan pribadi juga tidak dapat 
memperoleh kepuasan

dari hasil karya mereka.

Iklim kerja dalam sekolah/madrasah merupakan hal yang perlu mendapat perhatian dari seorang kepala sekolah, karena faktor tersebut sedikit banyaknya ikut mempengaruhi tingkah laku guru, pegawai dan peserta didik. Dengan demikian hendaknya sekolah berkembang secara dinamis, mengarah pada yang lebih baik untuk kelangsungan dan kemajuaan pendidikan. Salah satu cara dalam pengembanganorganisasi sekolah adalahlebih mementingkan iklim komunikasi organisasi dibanding tampilannya. Karena melalui macammacam teknik komunikasi bisamenciptakan sebuah organisasi yang efektif dengan menjelaskan performasi guru, dalam hal itu bahwa keadaan kerja yang lebih baik akan memberikan dorongan berprestasi yang lebih tinggi.

Iklim kerja di sekolah/madrasah adalah suasana bekerja, belajar, berkomunikasi dan bergaul dalam organisasi pendidikan. Berkenaan dengan standar kinerja guru dapat dilihat dari kualitas guru dalam menjalankan tugasnya seperti bekerja dengan siswa secara individual, persiapan dan perencanaan pembelajaran, pendayagunaan media pembelajaran, melibatkan siswa dalam berbagai pengalaman belajar, dan kepemimpinan yang aktif dari guru. Dengan terwujudnya iklim kerja sekolah yang baik dan komunikasi warga sekolah yang baik, maka seluruh warga sekolah/madrasah akan merasa nyaman dalam bekerja dan terpacu untuk bekerja lebih baik, suasana sekolah/madrasah yang kondusif sangat mendukung peningkatan kinerja. Kinerja guru akan menjadi optimal bila diintegrasikan dengan iklim kerja sekolah.

Maka dapat penulis katakan setelah melakukan wawancara kepada beberapa informan bahwa di MTs Al-Muttaqin tidak menggunakan Iklim kerja bebas untuk seluruh elemen-elemen sekolah yang ada, melainkan lebih kepada iklim kerja 
terbuka.Terbukti dari pandangan peneliti dan jawaban-jawaban dari beberapa objek wawancara dapat disimpulkan adanya suasana yang melukiskan organisasi sekolah yang penuh semangat dan daya hidup, dengan memberikan kepuasan pada anggota kelompok dalam memenuhi kebutuhan-kebutuhan, dan tindakan pemimpin yang sejalan dan serasi. Hal itu tergambar didasarkan pada rasa hormat, kepercayaan dan kejujuran serta memberikan peluang kepada guru dalam memanajemen madrasah dan peserta didik untuk terlibat dan koopratif antara satu sama lain.

Terdapat berb agai faktor yang mempengaruhi suasana kerja di madrasah. Oleh karenanya, agar dapat mengetahui kondisi/situasi iklim kerja yang ada di madrasah dapat diukur dengan menggunakan beberapa macam dimensi, menurut Litwin dan Stringer dalam Hamzah Bdiantaranya: ${ }^{9}$

9 Hamzah B, Teori Kinerja dan Pengukurannya, (Jakarta: Bumi Aksara 2012), 66-71
1. Tanggung jawab; karyawan diberi tugas kebebasan untuk melaksanakan tugas dan menyelesaikannya, diberi motivasi lebih untuk melaksanakan tugas tanpa harus selalu mencari persetujuan manajer, diberi keberanian menanggung resiko dari pekerjaan tanpa takut dimarahi.

2. Fleksibelitas; karyawan diberi kebebasan untuk lebih inovatif.

3. Standar; diperlukan untuk mencapai hasil yang memuaskan ditandai dengan adanya dorongan untuk maju.

4. Komitmen tim; orang akan memberikan apa yang terbaik yang mereka bisa lakukan jika mereka memiliki komitmen dalam organisasi.

5. Kejelasan; kejelasan apa yang menjadi tujuan, tingkatan tanggung jawab, nilai-nilai organisasi. Hal ini penting agar 
karyawan tahu apa yang sesungguhnya diharapkan dari mereka dan dapat memberikan kontribusi yang tepat bagi organisasi.

Maka dari itu, berlandas pada jawaban-jawaban yang penulis dapatkan di lapangan, dalam prosedur penetapan kebijakan madrasah, Kepala Madrasah menetapkan berdasarkan kesepakatan melalui forum rapat yang sudah menjadi kegiatan dalam kelender akademik untuk pencapaian target pendidikan di madrasah tersebut. Oleh karena itu, keberhasilan dan kegagalan dari pekerjaan yang dilakukan mendapatkan respon baik dari atasan, dan hal itu menjadi salah satu acuan dalam menumbuhkan semangat kerja dan perbaikan kerja semua pegawai yang ada. Dari hal tersebut maka bisa dikatakan bahwa iklim kerja di MTs Al-Muttaqin telah menerapkan iklim terbuka. Bukan hanya memfokuskan pada satu gagasan, tapi memberi kesempatan kepada warga sekolah dalam mengutarakan gagasannya, yang dapat menunjang perbaikan dan pencapaian tujuan yang akan dicapai. Sehingga dari sini juga terlihat adanya komunikasi timbal balik antar sesama atau dari pimpinan kepada bawahan. Karena dari pemaparan jawaban dari informan penelitian, bahwa di MTs Al-Muttaqin jelas akan pembagian prosedur tugas dan tanggung jawabnya sesuai dengan jabatan yang telah didudukinya, juga memiliki upaya dalam meningkatkan apresiasi dengan pemberian penghargaan bagi yang pencapainnya lebih baik dan sanksi bagi yang bermasalah, hal itu tentu telah mendapat kesepakatan bersama dan dijalankanbersama.

\section{Pembentukan Iklim Madrasah Islami}

Sekolah/madrasah menurut paraahli, merupakan sebuah lembaga yang didirikan dengan semangat mengintegrasikan nilainilai keislaman ke seluruh aspek yang ada di sekolah/madrasah. Definisi iklim Madrasah yang Islami 
(Islamic school climate) adalah norma, harapan, dan keyakinan Islam yang mewarnai sistem sosial sekolah/madrasah dan dipersepsi oleh seluruh anggota sekolah dan terintegrasi pada seluruh aspek yang ada di sekolah/madrasah. Integrasi nilai agama dalam iklim sekolah/madrasah dilakukan baik pada content yakni nilai, kurikulum, norma dan peraturan, program. Lalu conduct yaitu perilaku dan pelaksanaan pembelajaran, dan yang tekahir adalahcontext yaitu lingkungan sekolah. Iklim madrasah Islami berpijak pada delapan nilai yang melandasi dan menjiwai seluruh warga yang ada sekolah/madrasa. ${ }^{10}$ Bagaimana kinerja mereka, iklim kerja di antara mereka dan komunikasi atar sesama di sekolah/madrasah. Warga sekolah/madrasah tersebut meluputi pimpinan (Kepala

10 Alaydroes, F, Kepemimpinan Berbasis Nilai dalam Konteks Peningkatan Mutu Pendidikan. (Universitas Pendidikan Indonesia)

11 Daniel dkk, Hubungan Antara Iklim dan Budaya Madrasah Dengan Motivasi Kerja Guru Pada Madrasah Tsanawiyah di kecamatan sekolah/madrasah beserta para wakilnya), ketua yayasan (jika di lembaga pendidikan swasta), staf akademik, staf administrasi, guru, komite sekolah, maupun siswa ataupun petugas pelayanan khusus (security, cleaning service) dalam menjalankan seluruh tugas dan tanggungjawab mereka dalam pencapaian tujuan pendidikan.

Iklim madrasah sebagaimana dikemukakan Sagala merupakan serangkaian sifat lingkungan kerja yang dinilai langsung atau tidak langsung oleh warga madrasah dapat menjadi kekuatan utama dalam memengaruhi perilaku mereka. Ungkapan tersebut menunjukkan seperangkat karakteristik internal yang dideskripsikan oleh individuindividu sebagai iklim organisasi (madrasah).11 Menurut Rahmawati, untuk dapat membentuk iklim

Sinjai Barat Kabupaten Sinjai, Jurnal manajemen pendidikan, Volume 14 Nomor 1 , Juli 2019, $65 . \quad$ Dalam http://joernals.ums.ac.id/index.php/jmp/a rticle/dowload/8357/4745 diakses pada tanggal 22 Desember 2019, pukul 11:27. 
Madrasah Islami ada 8 nilai yang digunakan untuk dikatakan sebuah madrasah memiliki iklim Islami. ${ }^{12}$ Kedelapan nilai berkesinambungan dan saling mempengaruhi satu sama lain dalam masing-masing pasangannya. Nilai-nilai tersebut yaitu: Iman-Akhlaq/God oriented belief $\mathcal{E}$ behavior (keyakinan dan moralitas) ,Iltizam-Jiddiyah/ commitment $\mathcal{E}$ excellence (komitmen dan kesungguhan mencapai keunggulan), Adil-Ukhuwwah/fairness $\mathcal{E}$ solidarity (kesetaraan dan persaudaraan), sertaAmanahKhidmah/trustworthyEservingothers (dapat dipercaya dalam menunaikan tanggungjawab dan bersifat memberikan pelayanan.

$$
\text { Iltizam (commitment) }
$$

merupakan suatu sikap teguh dan komitmen dalam memperjuangkan tujuan luhur sekolah/madrasah, tetap berpijak kepada niat dan tujuan sebagaimana yang telah ditetapkan dan menjalankannya dengan penuh kesetiaan. Sementara jiddiyah (excellence) adalah bukti dari iltizam. Bekerja, beraktivitas dan belajar dengan sungguh-sungguh, mengerahkan seluruh sumber daya yang ada, baik waktu, tenaga, fikiran, dan harta. Hal tersebut sesuai dengan firman AllahSWT:Dan katakanlah: “Bekerjalah kamu, maka Allah dan rasul-Nya serta orang-orang mukmin akan melihat pekerjaanmu itu, dan kamu akan dikembalikan kepada (Allah) yang mengetahui akan yang ghaib dan yang nyata, lalu diberitakan-Nya kepada kamu apa yang telah kamu kerjakan" (QS. At Taubah ayat 105). Berdasarkan firman Allah SWT tersebuat, maka seharusnya seluruh warga madrasah memiliki dorongan yang kuat untuk terus bekerja, beraktivitas dan belajar untuk mencapai keunggulan.

Adil dalam konteks mendidik, berarti memberikan sebuah perhatian, fasilitas dan layanan pembelajaran kepada seluruh 
peserta didik tanpa diskriminasi sesuai dengan tingkat kebutuhannya masing- masing. Allah SWT berfirman: "Sesungguhnya Allah menyuruh (kamu) berlaku adil dan berbuat kebajikan, memberi kepada kaum kerabat dan Allah melarang dari perbuatan keji, kemungkaran dan permusuhan. Dia memberi pengajaran kepadamu agar kamu dapat mengambil pelajaran". (QS Surah An-Nahl: 90). Berdasarkan firman Allah SWT tersebut, hendaknya para pimpinan Madrasah baik Ketua Yayasan ataupun Kepala Madrasah dapat adil dalam menjalankan tugastugasnya. Adil dalam pembagian kerja kepada para bawahanya, baik guru, tenaga administrasi madrasah (TAM), kepada para siswa, dan kepada petugas layanan khusus (Security dan Cleaning Service).

Amanah maknanya dapat menunaikan sebuah pekerjaan dengan sebaik-baiknya, yang berarti bekerja dengan ilmu dan kompetensi, dilakukan dengan cara-cara yang sesuai dengan pedoman dan tuntutan profesionalitas. Menunaikan pekerjaan maupun apapun dengan cara yang baik sesuai dengan kaidah ihsanul 'amal, yaitu bekerja dengan baik, tertib, sesuai aturan, rapih, efisien dan efektif. Islam memerintahkan untuk selalu bertindak dan bekerja dengan sebaik-baiknya, sebagaimana sabda Nabi Muhammad SAW: "Sesungguhnya Allah mewajibkan bertindak 'ihsan: baik, sesuai, benar, efisien dan efektif atas segala sesuatu (pekerjaan)."Sedangkan khidmah atau melayani dengan sepenuh hati. Nabi Muhammad SAW menyampaikan keutamaan menolong atau memberi bantuan kepada sesame dalam sabdanya: “Barang siapa yang melepaskan satu kesusahan seorang mukmin, pasti Allah akan melepaskan darinya satu kesusahan pada hari kiamat. Barang siapa yang menjadikan mudah urusan orang lain, pasti Allah akan 
memudahkannya di dunia maupun di akhirat."

\section{Iklim Kerja Warga Madrasah} Membentuk Iklim Madrasah Islami Iman wa akhlaq (God oriented belief and behavior)

Sebagai sebuah madrasah yang memiliki visi dan misi menyelenggarakan pendidikan yang mengacu kepada nilai-nilai Islam, Mts Al-Muttaqin mendasarkan seluruh aktivitas pendidikan dan pembelajaran dengan semangat pengabdian kepada Allah SWT yang diwujudkan dalam bentuk keyakinan terhadap Allah sebagai Yang Maha Esa, serta akhlaq yang terjaga dalam keseharian menjalankan tugas. Mengacu pada analisis iklim kerja warga Mts AlMuttaqin, bahwa warga Mts AlMuttaqin bekerja dengan suasana yang senang walapun di lingkungan yang tidak luas dan dengan bangunan madrasah yang sederhana seluruh elemen-elemen madrasah melaksanakan tugas dengan baik dan dari hati.
Mengingat bahwa seluruh kegiatan yang mereka lalukan adalah ibadah, maka mereka yakin bahwa selain pihak yayasan Madrasah memberikan hak-hak kepada mereka, Allah lebih memberikan apa yang mereka butuhkan. Ada sebuah niat yang tulus pada mereka untuk beraktivitas dalam lingkungan madrasah lillahta'ala dan percaya Allah melihat apapun yang mereka dilakukan selama di madrasah khususnya.

\section{1) Iltizam wa Jiddiyah}

\section{(Commitment and excellence)}

Kurikulum pendidikan yang ada di Mts Al-Muttaqin disusun sedemikian rupa agar sesuai dengan visi-misi dan nilai madrasah. Berdasarkan wawancara dan observasi, penulis melihat bahwa adanya iklim kerja yang terbentuk dari rasa mau untuk melakukan. Para guru berkerja keras demi kelancara proses pemebalajaran, tenaga administrasi pun bekerja semampu mereka untuk tetap melayani layanan administrasi yang diperlukan 
madrasah. Tenaga layanan khusus seperti security bekerja sepenuh hati menjaga keamanan lingkungan madrasah ada rasa tangggung jawab yang besar untuk melaksanakanya. Begitu juga dengan para siswa yang selalu ada rasa ingin tau untuk selalu belajar dari apa yang belum mereka ketahui.

\section{2) Adil wa ukhuwwah (Fairness and solidarity)}

Seluruh peserta didik, orang tua atau wali dari peserta didik, pihak yayasan dan masyarakat adalah mitra terpenting dalam pelaksanaan pendidikan di madrasah. Kegiatan yang dilakukan oleh madrasah tidak lepas dari prinsip keadilan dan ukhuwwah, yaitu dengan meletakkan segala sesuatu pada tempatnya secara tepat sesuai dengan kemampuanya guna menjalankan tugas dan fungsinya. Ukhuwwah maknanya ada rasa saling percaya, rasa persaudaraan, saling sepenanggungan dan kemauan untuk saling berbagi dengan sesama. Pihak yayasan dan
Mts Al-Muttaqin memiliki iklim kerja ukhuwah yang kuat dalam mengelola pendidikan, keduanya saling bersinergi dan melengkapi apa yang menjadi kekurangan untuk mencapai mutu yang unggul. Begitu pula pada seluruh stakeholders yang ada, saling menguatkan untuk membantu tercapainya tujuan pendidikan di Mts Al-Muttaqin dngan baik. Hubungan antar pegawai dan guru terlihat sangat erat, hasil kebijakan yang akan madrasah keluarkan pun atas dasar musyawarah bersama.

\section{3) Amanah wa khidmah (Trustworthy and serving others)}

Menjalankan tugas secara amanah berarti mengelola tugas dengan ilmu dan kompetensi sehingga profesionalitas dapat terwujud. Nilai Amanah maknanya mampu bersikap melayani orang lain dengan sepenuh hati, dengan adanya dorongan untuk berbuat kebaikan serta memperoleh kemudahan dari Allah untuk urusan dunia maupun akhirat. 
Seluruh elemen yang ada di Mts Al-

Muttaqin berupaya untuk menjalan tugas dan kewajibannya sesuai dengan tugas dan fungsi yang telah ditetapkan oleh kepala yayasan atau kepala Madrasah. Para guru mendidik dan mengajar siswanya dengan sebaik-baiknya agar hakhak siswa di madrasah dapat terpenuhi. Begitu pula dengan tenaga administrasi madrasah yang senantiasa melayani dengan baik untuk memenuhi keperluankeperluan madrasah atau keperluan wali siswa.

Sehingga dapat dikatakan bahwa dalam pembentukan iklim madrasah islami di atas terdapat proses pendidikan madrasah yang melalui arena cukup luas, maka perlu dipertimbangkan adanya prioritas. Prioritas yang perlu diperhatikan dalam pengembangan iklim madrasah adalah modernisasi pengelolaan sekolah, modernisasi

\footnotetext{
${ }^{13}$ Lailatu Zahro, Urgensi Pembinaan Iklim dan Budaya Sekolah, Jurnal Pendidikan Agama Islam, Volume 3 Nomor 1, April 2015, hlm $163-186$

dalam https://media.neliti.com/media/publication
}

guru, dan modernisasi pembelajaran. ${ }^{13}$ Sejalan dengan uraian tersebut pemerintah terus menerus melakukan berbagai kajian, baik melalui diskusi, seminar, lokakarya maupun pengkajian-pengkajian para ahli lainnya. Dari berbagai pengkajian tersebut, Departemen Pendidikan Nasional telah mengagendakan berbagai program perubahan yang harus dilakukan untuk menciptakan iklim sekolah/madrasah yang kondusif dan menunjang terhadap pencapaian tujuan pendidikan. Program perubahan tersebut mencakup level kelas (regulator), level profesi (mediator) dan level sekolah (manajemen). ${ }^{14}$

\section{TEMUAN PENELITIAN}

Iklim kerja yang telah ada di MTs Al-Muttaqin belumlah sepenuhnya menghasilkan hasil

s/117551-ID-urgensi-pembinaan-iklim-danbudaya-sekolah.pdf dikases pada tanggal 22 Desember 2020, pukul 11:23.

14Depdiknas, dalam E. Mulyasa, Manajemen \& Kepemimpinan..., 2012. 
yang terbaik, melainkan masih adanya beberapa kendala yang dapat menghambat atau mencegah keberhasilan. Contohnya, masih terdapat kekurangan pemantauan dan komunikasi yang berkelanjutan antar pihak yayasan dengan madrasah, antar pihak madrasah dengan wali siswa atau masyarakat. Namun hal itu dapat tertutupi dengan adanya banyak upayaupaya dalam menumbuhkan iklim kerja yang baik di MTs Al-Muttaqin yang dilakukan oleh guru, murid, dan warga sekolah lainnya yang dapat menyeimbangi kendala yang ada. Terlihat dari sosial tinggi dan hubungan harmonis antar guru dengan panggilan keakraban, dan lain sebagainya. Sehingga merujuk pada hal tersebut, Iklim kerja yang baik dan menyenangkan di MTS AlMuttaqin dapat dirasakan murid yaitu, berupa keterlibatan sekolah yang menjalin kerja sama antar sekolah lain dengan mengirim atau mengikutsertakan beberapa murid Al-Muttaqin ini dalam ajang kompetisi yang dapat dijadikan sebuah apresiasi kepada murid yang berprestasi untuk mengembangkan potensi dengan bakat dan kemampuan yang dimiliki dengan mengikuti perlombaan antar sekolah sejenjang.

Secara keseluruhan jawaban atas wawancara dengan para stakeholders sekolah bahwa MTs AlMuttaqin memiliki iklim kerja madrasah yang dikatakan baik, nyaman, tertib, bersih, indah dan menyenangkan dari suasana bekerja, belajar, berkomunikasi dan bergaul dalam organisasi pendidikan yang sedang terjalin. Terutama yang terlihat dari hal yang berkenaan dengan standar kinerja guru atas kualitas guru dan tenaga lainnya dalam menjalankan tugasnya, seperti bekerja saat masuk kelas tepat waktu, mengoreksi hasil ujian, penerimaan siswa baru, mengawas ujian, dan para murid yang tertib dengan waktu keluar kelas. Selain itu dengan komunikasi yang baik, apresiasi yang ada, hubungan harmonis yang terjalin. Yang tergambar pada peranan di setiap warga sekolah yang 
dapat menunjang iklim kerja yang bertanggung jawab, dengan keterlibatan peran sesuai dengantugasnya. Maka dengan adanya iklim kerja madrasah yang baik akan berimplikasi pula pada penciptaan iklim madrasah yang Islami.

\section{SIMPULAN}

Iklim kerja yang terbentuk di Mts Al-Muttaqin sudah tergolong dan terindikasi baik walaupun masih ada beberapa kendala pengawasan untuk mencapai kesempurnaannya. Dengan terciptnya iklim kerja madrasah yang baik, maka Iklim Madrasah Islami pun mudah untuk diciptakan.Dengan adanya nilai-nilai yang dapat dibentuk dan dipraktekkan oleh seluruh komponen atau warga yang ada di Mts Al-Muttaqin. Nilai-nilai tersebut adalah iman dan akhlaq (God oriented belief and behavior), Iltizam dan Jiddiyah (Commitment and excellence), Adil dan ukhuwwah (Fairness and solidarity), Amanah dan khidmah (Trustworthy and serving others). 


\section{DAFTAR PUSTAKA}

Al-Qur'anul Karim \& Terjemahan. Departemen Agama RI, 2013

Alaydroes, F, Kepemimpinan Berbasis Nilai dalam Konteks Peningkatan Mutu Pendidikan. Universitas Pendidikan Indonesia, 2012

Arikunto, Suharmisi, Dasar-dasar Evaluasi Pendidikan, Jakarta: Bumi Aksara, 2008

Astuti, Pengembangan Budaya dan Iklim Sekolah, diambil dari http://jurnal.iainbone.ac.id/index.php/adara/ar ticle/dowload/267/217. (diakses pada tanggal 22 desember 2019, pukul 11:24)

B, Hamzah, et al, Teori Kinerja dan Pengukurannya, Jakarta: Bumi Aksara, 2012

Daniel dkk, Hubungan Antara Iklim dan Budaya Madrasah Dengan Motivasi Kerja Guru Pada Madrasah Tsanawiyah di kecamatan Sinjai Barat Kabupaten Sinjai, Jurnal manajemen pendidikan, Volume 14 Nomor 1, Juli 2019, hlm 65. Diambil dari http://joernals.ums.ac.id/inde x.php/jmp/article/dowload/8 357/4745(diakses pada tanggal 22 Desember 2019, pukul 11:27).

Depdiknas, dalam E. Mulyasa, Manajemen \& Kepemimpinan...,
Irwan, Iklim Sekolah di SMKN 1 Papalang Kabupaten Mamuju, Jurnal Eklektika Volume 4 Nomor 1, April 2016, hlm 61. Diambil

darihttp:/ / ojs.unm.ac.id/ekleti $\mathrm{ka} /$ article/download/5675/331 2(diakses pada tanggal 22 Desember 2019, pukul 11:26).

Jimerson, S.R., Swearer, S.M., \& Espelage, D.L. (2009).International Handbook of School

Bullying: An InternationalPerspective.Diambil dari

https:/ / books.google.co.id/boo ks?id=d2-

NAgAAQBAJ(Diakses pada tanggal 16 Desember 2019, pukul 19:00 WIB)

Indonesia, Keputusan Menteri Agama Republik Indonesia Nomor : 165 Tahun 2014 Tentang Kemendikbud. (2013). Kurikulum 2013 Mata Pelajaran Pendidikan Agama Islam dan Bahasa Arab Pada Madrasah.

Lailatu, Zahro, Urgensi Pembinaan Iklim dan Budaya Sekolah, Jurnal Pendidikan Agama Islam, Volume 3 Nomor 1, April 2015, hlm 163-186, diambil dari https://media.neliti.com/medi a/publications/117551-IDurgensi-pembinaan-iklim-danbudaya-sekolah.pdf (Diakses pada tanggal 22 Desember 2020, pukul 11:23). 
Rahmawati, Sri W, Edukasia: Jurnal Penelitian Pendidikan Islam, 2019

Ryan,W.

(2009).

Linksbetweenschoolclimateandbullyi ng:Astudyof twotribesschools.Diambildarihttp:/ / search.proquest.com/docview/ 205390932? accountid=17242(Di akses pada tanggal 16 Desember 2019, pukul 19:00 WIB)

Supardi, Kinerja Guru, Jakarta: RajaGrafindo Persada, 2010

Yamin dan Maisah. Standarisasi Kinerja Guru, Jakarta: Gaung Persada Press, 2010 